\title{
Role of Capital Structure and Institutional Ownership to Improve the Financial Performance: Evidence from Jordan
}

\author{
Huthaifa Karasneh ${ }^{1}$ \\ Department of Financial and Administrative Sciences, AL-Balqa Applied University/ Irbid University \\ College, Jordan, Email: huthaifa85@bau.edu.jo \\ Dr. Ashraf Bataineh ${ }^{2}$ \\ Department of Financial and Administrative Sciences, AL-Balqa Applied University/ Irbid University \\ College, Jordan, Email: bataineh_ashraf@bau.edu.jo \\ Dr. Mohamed Mahmoud Bshayreh ${ }^{3}$ \\ Department of Financial and Administrative Sciences, AL-Balqa Applied University/ Al-Huson \\ University College, Jordan, Email: mbsh1979@bau.edu.jo
}

\begin{abstract}
The study aimed to identify the role of capital structure and institutional ownership to improve the financial performance at Jordanian real estate companies. Study population consisted of all (34) Jordanian real estate companies listed on the Jordan Stock Exchange during the period (2015-2017). The most important results of the study include: there is a positive relationship for the capital structure and institutional ownership to improve the financial performance at Jordanian real estate companies through (ROA, ROE, EPS), and also there is a positive relationship between the company size measured by total assets and the financial performance of Jordanian real estate companies. Based on the above results, researchers made a number of recommendations, such as the need for private investment companies to support investments in the Jordanian real estate companies by raising the institutional ownership or property ratios, in order to increase the amount of capital in these companies.
\end{abstract}

Keywords: Capital Structure, Financial Performance, Institutional Ownership, Jordanian Real Estate Companies.

\section{Introduction}

Agency theory represents references of prominent theoretical framework in all literature of strategic management, finance, and economic, which can be used to study the relationship between ownership and performance (Shleifer \& Vishny, 1997), and also emphasize that managers and agents normally have conflict in the objectives and capabilities that may affect corporate behaviours and end results (Milgrom \& Roberts, 1992). Capital structure of firms may be shaped by the agency costs, as speculated by the agency theory and contain the liability and equity cost (Al-Karasneh \& Bataineh, 2018), and capital structure theory consider one of the most important reference theories in the financial policies of companies and consider one of the essentials in any commercial business, due to the need to maximize profits of stakeholders, and also due to the fact that such decision would significantly affect the ability of firms to deal with competitive environment.

One of the critical issues that face organizations' managers today reside in selecting the appropriate mix of liability and capital that achieve the optimal capital structure by reducing company's capital cost to the lowest way possible and increasing the returns for business owners, and even if companies normally have the appropriate alternative to combine between liability and capital, managers are trying to identify the specific structure that will lead to double company's profitability and market value (Watson \& Head, 2007). Capital structure alternatives and its most encouraging risk disclosure is very dominant in company's economic performance, due to the fact that making a choice between liability and capital should eventually raise up the growth of investment value made by investors in general, and equity or capital investors in particular (Watson and Head, 2007). This is really important due to the fact that equity investors have greater expectation of returns on investment, in the way of higher dividends and capital gain (Sulaiman, 2001), but any results that conflict with the investors or shareholders expectation will lead to reduce the company's share value, and this reduction will send an indication to the prospective investors about the company's weak performance, which discourage those investors from investing in liability and capital shares (Bataineh \& Rababah, 2016). 
There are numerous theories that have been moved forward to enlighten the capital structure of firms, but there is disagreement among the researchers of financial management about the most favorable capital structure. These differences in the numerous theories refer to the importance of decision making related to capital structure and are very critical, mainly with respect to firm performance, its profitability, and capital value (Awunyo-Vitor \& Badu, 2012).

Therefore, this study gets its significance from the role that Jordanian shareholding companies play in developing and fostering the Jordan's economy (Rababah \& Bataineh, 2016), where capital structure consider a way to help companies finance itself through making a combination between the responsibility, capital, and securities, in addition to the fact that company's capital structure is very important due to its connection with company's ability to fulfill the shareholders needs.

This study consider very important for both researchers and business analysts, due to its relationship with the topic of capital financing, and it adds to the current literatures by verifying the classical theory of capital structure. Therefore, the objective of current study is to identify the contribution level of capital structure and institutional ownership to improve the financial performance in Jordanian Real Estate Companies listed at ASE during the period (2015-2017), which are represented in ROE, ROA, EPS and EP.

\section{Literature Review}

\subsection{The Role of Capital Structure on Firms Performance}

Company's capital structure consider an important element to strengthen its functional processes, where many of the previous studies aimed to develop and implement theories to help companies select the appropriate capital structure combination, which will strengthen their businesses and raise the value of stakeholders.

The study of Kinsman and Newman (1999) indicate that examining the relationship between debt level of capital structure and companies' performance is very essential due to the following reasons: first, the explanation of debt level impact on firms performance becomes a necessitate due to the fact that major firm debt level grows considerably during the previous periods, therefore the suitable debt level decisions can be made in a specific firm. Secondly, the relative strengths of any specific effects of debt on firms performance must be known, due to the fact that current managers and investors in the firms are not the same, and finally and most importantly, investigate the relationship between debt level and shareholders wealth, whereas the major objective of firms' managers will be to raise the capital and moneybag of shareholders.

But the study of Buferna, et al (2005) aimed to provide some practical evidences for the capital structure theories at the developed countries' firms. Study sample consist of (32) public and (22) private companies, and stand on treating the data from (55) public and private companies in 5 years interval between (1995-1999), where the financial leverage report as the independent variable and each of firm size, firm growth opportunities, firm assets debt ratio, and firm profitability as the dependent variables, and to investigate the relationship between debt level dependent variables with those used economic-metric as a method to test the amount of small squares. Study results showed that private companies got the highest average growth rate and more assets than the public companies, which indicate that companies with higher levels of fixed assets have a tendency to use more debt than long-term debt, but large and profitable companies are likely to use debt in general.

In a country like Egypt, the study of Ibrahim (2009) showed a significant correlation between short term debt and total debt on firm performance, whereas it didn't show any significant relationship between long term debt, ROE, and GM. Generally in Egypt, it indicates a weak impact of leverage on firm performance.

The relationship between capital structure and firms performance in developed countries are diverse, according to numerous practical studies, however there are a few studies, that practically inspect this relationship in the transformational economies. As an example, Majumdar \& Chhibber (1999) investigated the relationship between capital structure and Indian firms' performance, taking into account that debt level has a reverse relationship with performance, but Chiang et al. (2002) analyzed property and construction sector firms in Hong Kong, where the relationship between capital structure and performance was examined and indicate a negative relationship with performance (i.e. profit margin), and the Kyereboah-Coleman (2007) study analyzed the relationship between capital structure and the performance of small financial institutions based in sub-Saharan Africa, and found that high leverage has a positive relationship with performance (i.e. ROA \& ROE), while Zeitun and Tian (2007) inspected the relationship between capital structure and performance of Jordanian firms is by where, and found a negative relationship between debt level and performance (both the accounting and market measures). In addition, Abor (2007) studied the relationship between liability policy (capital structure) and the performance of small and medium size enterprises in Ghana and South Africa, where the study found that capital structure, especially long-term and total debt level is negatively related to performance (both the accounting and market measures). 
The study of Muritala (2012) aimed to determine the most advantageous level of capital structure, which companies through it can raise its financial performance in Nigeria using the yearly data of ten firms for five-year period. Study results indicate that asset turnover; size, firm's age, and firm's tangible asset have a positive relationship with firm's performance (ROA), but found a negative relationship between tangible asset and ROA as a measure of performance. Likewise, Babalola (2012) examined the way that finest capital structure can capitalize on the performance of selected firms under the same methodical risk by investigating the relationship between return on equity (ROE) and the capital structure for a sample of (10) firms in Nigeria during the period (2000-2009). Researcher noticed that finest capital structure and their related extreme value of ROE may eventually change, along with the changes in firm's performance and environments while firms correct their capital structure to align with the most favorable debt ratio and agree with the previous financial behaviors of firms.

\subsection{The Role of Institutional Ownership on Firms Performance}

The institutional investors have a tendency to invest in firms with specific characteristics (e.g., Bennett et al., 2003; O'Brien \& Bhushan, 1990). There is also several evidence that institutional ownership has a positive relationship with firm performance (e.g., Del Guercio \& Hawkins, 1999; Cornett et al., 2007). The literature on Real Estate Investment Trust (REIT) institutional holdings is noticeably less developed, where there were fractional list of prior studies that inspected REIT institutional ownership include (Below et al., 2000); Ghosh \& Sirmans, 2003). These studies documented the collective proportion of holdings for REIT institutions during (1980-1990), and largely indicate an impressive increase in the collective institutional holdings of REITs.

Another set of literature investigate the relationship between REIT returns and institutional ownership, and found that institutional ownership and REIT performance are positively correlated (e.g., Downs 1998; Chan et al. 2003), where these findings are seemingly related to our study.

The study of Pirzada, et.al (2015) aimed to determine the significant relationship between institutional shareholders and firms' performance by ROA, ROE, PE, EPS and capital structure, measured by the long term debt to capital ratio of companies listed on the Main Board of Malaysian Stock Exchange. Study results indicate a significant relationship between the institutional shareholders and firms' performance measured by EPS and PE ratio of firms listed on the Malaysian Stock Exchange. In addition, it didn't show any significant relationship between the institutional shareholders and firms' performance of capital structure.

\section{Theoretical Framework}

\subsection{Capital Structure}

Writers identify capital structure differently through their writing, but as mentioned by (Uremadu, 2004) it's the relationship that exists between a variety of capital categories, which may be adopted by the different firms to finance its operations. In another way, it's an interaction between firm's internal financial resources, such as liability capital and equity capital to determine which capital mix should be implemented by the businesses to finance its operations. This means that debt or equity financing truly encourage the managers to efficiently manage the company's affairs, where Heaton (2002) agree with the argument that making a decision related to the capital structure of a firm could be determine by the company's management. This due to the fact that most managers are normally over convinced about their capabilities, and as a result they will be upset to issue equity interests as they feel that more equity capital being issued, the more the value of their firm to be underrated. Its known that most shareholders are unconvinced about the reliability of the information displayed to them by company's management under debate, where they would like to show their company as doing well while its not, and even if company decided to settle for the choice of debt capital in its capital structure, it still will be present as a choice for a debt type that may be used to finance the firms' operations. Capital structure decision can be defined as a mix between debt and equity which company select to finance its business operations (Damodaran, 2001), and as a result capital structure becomes a major issue in the financial economies ever since Modigliani and Miller indicated in 1958 that given less resistance in the market, capital structure could have two effects; and as said by Desai (2007) firms of the same threat level could probably have higher capital cost along with higher control.

\subsection{Institutional Ownership}

Researches in the past frequently did categorize the institutional investors depend on the following three things: independent business relationships with invested companies, geographical origin, and stocks size. Regarding the first point, the stockholders who are pressured by insensible institutions are expected to have positive influence on company's performance as they are unlikely to do business with investee firms and usually there have no conflict of interests between them, therefore they are probably going to control investee firms effectively, and demand managers to capitalize on shareholder value. 
On the contrary, institutions that have been pressured from sensitive institutions tend to protect its trade relations with invested companies and operate as non-active investors (Cornett et al., 2007; Ferreira \& Matos 2008).

In regard to the second point, global invested companies are usually more occupied with controlling the invested companies activities, and more prone to request changes in corporate governance from the local institutional investors, since the latter usually has a lot tougher business relationships with local investee firms, which could make them obliged to be devoted to management (Ferreira \& Matos 2008; Gillan \& Starks, 2003), but in regard to third point, shareholders of big investments are more motivated to keep an eye on invested companies due to their intend to collect more incentives than young contributors (Shleifer \& Vishny, 1986), thus the big stock investors (for example, with 5\% or more from the entire amount of excellent shares) have a larger motivation to develop corporate performance than the low equity investors (for example, with less than 5\% from the entire amount of excellent shares) (Elyasiani \& Jia, 2010).

Institutional investors request analysis reports in order to get the required information, especially information related to the fiduciary responsibilities, therefore more institutional ownerships would be more likely to raise their claims for analysis report services concerning investee firms (Frankel, et al 2006). In addition, any increase in the accuracy and confession of these firms might increase the analysts demand to create supplementary information, which result in more loyalty and less information irregularity (Boone \& White, 2015). Nevertheless, institutional investors can support management to obtain extra analyst reporting for the firm depend on their crucial associations with the financial markets, which can result in improving the liquidity of institutional equity and reduces the transaction and financing costs of the company (Elyasiani \& Jia, 2010). According to these different perspectives, we suggest that influencing analysts to follow investee firms consider a way for institutional ownerships to boost their performance.

\section{Research Methodology}

\subsection{Data Collection}

In order to examine the role of capital structure and institutional ownership to improve the financial performance, the study took a sample of public companies listed on Amman stock exchange, where the sample represented all (34) public shareholding real estate companies, after excluding one company for lack of required statement during the period (2015-2017), where data were collected about the study variables through the annual reports of these companies, through the official website of the Jordanain national securities, and corporate websites, in addition to the financial ratios and accounts listed in Amman stock exchange. The study used Spearman correlation coefficient to test the relationship between variables, which align with the study variables due to its abnormal distribution. Hazra \& Gogtay (2016) noticed that abnormal distribution or presence of outliers provide unclear picture of the relationship between two random variables, where the Spearman correlation coefficient is a non-parametric test that may be used in place of the Pearson's correlation coefficient.

\subsection{Research Hypotheses}

The following hypotheses have been tested in this study:

Main hypothesis $\mathrm{Ho}_{1}$ : There is no statistical significant relationship between the capital structure, institutional ownership and financial performance at the Jordanian real estate companies.

Sub-hypothesis $\mathbf{H 0}_{1-1}$ : There is no statistical significant relationship between the capital structure and firm performance at the Jordanian real estate companies.

Sub-hypothesis $\mathbf{H O}_{1-2}$ : There is no statistical significant relationship between the institutional ownership and financial performance at the Jordanian real estate companies.

Sub-hypothesis $\mathbf{H 0}_{1-3}$ : There is no statistical significant relationship between the capital structure, institutional ownership and financial performance, due to the controlled variables (Firm size) at the Jordanian real estate companies. 
Table (1) study variables and its measurement methods

\begin{tabular}{|c|c|}
\hline Independent Variables & Measurement Methods \\
\hline Institutional Ownership (IO) & Percentage of institutional ownership / equity \\
\hline Capital Structure (CS) & long term debt to capital ratio \\
\hline Control Variables & Measurement Methods \\
\hline Firm Size (FS) & Total assets in million JD \\
\hline Dependent Variables & Measurement Methods \\
\hline Firm Performance & Return on assets \\
\hline ROA & Return on equity \\
\hline ROE & Earnings per share \\
\hline EPS & EPS / stock price \\
\hline EP &
\end{tabular}

\subsection{Data Analysis:}

\section{Results of data analysis}

\begin{tabular}{|c|c|c|c|c|}
\hline \multicolumn{7}{|c|}{ Table (2) statistical description of variables } \\
\hline Variables & Mean & Std. Deviation & Minimum & Maximum \\
\hline CS & 29.85 & 30.90 & .08 & 97.29 \\
\hline IO & .4151 & .30244 & .00 & .94 \\
\hline FS (in millions) & 32.21 & 41.8 & 0.998 & 167.57 \\
\hline ROA & -.92 & 5.34 & -25.78 & 9.10 \\
\hline ROE & -1.04 & 8.01 & -31.53 & 17.35 \\
\hline EPS & .0006 & -.008 & -.18 & .14 \\
\hline EP & 206.733 & 4.396 & -173.65 & 6099.14 \\
\hline
\end{tabular}

Table (2) shows the descriptive analysis results of the study variables, by using the descriptive statistical analysis methods represented in the arithmetic mean, standard deviation, maximum value, and minimum values available by the (SPSS) program during the study period, it also display the change and change percentage between the arithmetic means and effect type of each variable.

The descriptive analysis results of study variables indicate that all variables have positive arithmetic mean, as follows:

- The arithmetic mean of capital structure (CS) amounted to (29.85) through a standard deviation of (30.90) between $(0.08)$ as the lowest value and (0.97) as the highest value, and by comparing these results with some of the previous studies like Pirzada, et al. (2015) study, it show a big difference in the arithmetic mean, where it amounted to (19.17) for the sample that was implemented on the Malaysian companies listed in the financial market, with a difference of (10.68) between the two arithmetic means, but for the study of (Chen, 2003), the arithmetic mean of capital structure (CS) amounted to (15.5) and with a difference of (14.35) from the current study. In regard to the comparison of standard deviation which amounted to (0.30), there were differences of (15.92) between it and the study of Pirzada, et al. (2015), and (2.31) differences between this study and the study of (Chen, 2003). These results and comparisons indicate that ratio increase in the capital structure (CS) has generally a positive role in improving the financial companies' performance.

- The arithmetic mean of institutional ownership (IO) amounted to (0.42) through a standard deviation of (00.30) between (0.00) as the lowest value and (0.94) as the highest value, and by comparing these results with some of the previous studies like Pirzada, et al. (2015) study, it show a big difference in the arithmetic mean, where it amounted to (9.33) for the sample that was implemented on the Malaysian companies, with a difference of (8.91) between the two arithmetic means, but for the study of (Chen, 2003), the arithmetic mean of capital structure (CS) amounted to (43.3) and with a difference of (42.88) from the current study. In regard to the comparison of standard deviation which amounted to (0.30), there were differences of (9.66) between it and the study of Pirzada, et al. (2015), and (1.12) 
differences between this study and the study of (Chen, 2003). These results and comparisons indicate that ratio increase in the institutional ownership (IO) has generally a positive role in improving the financial companies' performance.

- The arithmetic mean of Firm Size (FS) amounted to approximately (32) through a standard deviation of (42) between (1) as the lowest value and (168) as the highest value, and this indicate the positive role of total assets size or firm size (FS) in improving the financial companies' performance in general.

- The arithmetic mean of return on assets (ROA) variable amounted to (-0.92) through a standard deviation of (5.34) between (-26) as the lowest value and (9) as the highest value, and by comparing these results with some of the previous studies like Pirzada, et al. (2015) study, it show a big difference in the arithmetic mean, where it amounted to (5.38) for the sample that was implemented on the Malaysian companies listed in the financial market, with a difference of (6.30) between the two arithmetic means. In regard to the comparison of standard deviation which amounted to (5), there were differences of (1.65) between it and the study of Pirzada, et al. (2015).

These results and comparisons indicate that ratio increase in the return on assets (ROA) has generally a major positive role in improving the financial companies' performance.

- The arithmetic mean of return on equity (ROE) variable amounted to (-1.04) through a standard deviation of (8.01) between (-32) as the lowest value and (17) as the highest value, and by comparing these results with some of the previous studies like Pirzada, et al. (2015) study, it show a big difference in the arithmetic mean, where it amounted to (8.69) for the sample that was implemented on the Malaysian companies listed in the financial market, with a difference of (9.69) between the two arithmetic means. In regard to the comparison of standard deviation which amounted to (8), there were differences of (12.41) between it and the study of Pirzada, et al. (2015). These results and comparisons indicate that ratio increase in the return on equity (ROE) has generally a major positive role in improving the financial companies' performance.

- The arithmetic mean of earning per share (EPS) amounted to approximately (-6) through a standard deviation of (-8) between (-18) as the lowest value and (14) as the highest value, and this indicate the positive role of earning per share (EPS) in improving companies' performance in general.

- The arithmetic mean of EPS/ stock price (EP) amounted to approximately (207) through a standard deviation of (4) between (-174) as the lowest value and (6099) as the highest value, and this indicate the positive role of EPS/ stock price (EP) in improving financial companies' performance in general.

Table (3) Nonparametric Correlation

\begin{tabular}{|c|c|c|c|c|c|c|c|}
\hline & FS & CS & IO & EP & EPS & ROE & ROA \\
\hline FS & 1000 & & & & & & \\
\hline CS & $.418^{*}$ & 1000 & & & & & \\
\hline IO & $.610^{* *}$ & 0.193 & 1000 & & & & \\
\hline EP & -0.169 & -0.034 & 0.058 & 1000 & & & \\
\hline EPS & 0.241 & 0.007 & 0.235 & 0.208 & 1000 & & \\
\hline ROE & 0.272 & -0.04 & 0.269 & 0.175 & $.960^{* *}$ & 1000 & \\
\hline ROA & 0.311 & 0.041 & 0.302 & 0.235 & $.960^{* *}$ & $.976^{* *}$ & 1000 \\
\hline
\end{tabular}

***Correlation is significant at level $(0.05)$

* Correlation is significant at level (0.01)

It shows through table (3) a statistically significant relationship between firm size (FS) and the capital structure (CS) at level (1\%), which reflects the role of debt financing on increasing the real estate assets. It showed a correlation between firm size (FS) and the institutional ownership (IO) at level (5\%), which indicates that the bigger the size of the company the more chance to have a positive relationship with the institutional ownership (IO), and this refers to the role of institutions to support real estate sector in Jordan. The results also showed a statistically significant positive relationship between earnings per share (EPS) and both of (ROE) and (ROA) at level (5\%), which indicates that many of the real estate companies have achieved good levels of profit, despite the consequences of global financial crisis and led to the growth of those companies and invest in it through the distribution of dividends on shareholders. In addition, the results showed a statistically significant positive relationship at level (5\%) between both of (ROE and ROA), which indicates a significant relationship between return on assets and return on equity to improving the financial performance at Jordanain real estate companies. 


\section{Conclusions}

This study was implemented on the public shareholdings Jordanain real estate companies listed on Amman Stock Exchange (ASE), which amount to (34) companies during the period (2015-2017), which has affected all economic sectors in Jordan, especially the real estate sector as a result of the consequences of global financial crisis and the surrounding political economical conditions, like the wars that occur in many neighboring countries such as Iraq and Syria, which started back in 2009 and still going until now.

Despite the recession that affect the real estate sector, due to the crises which have been mentioned previously but the results of this study showed a positive relationship between capital structure (CS), institutional ownership (IO) and firm size (FS) to improving the performance at Jordanian real estate companies, as the main topic and sample of the study. But in regard to the role of Jordanian real estate companies performance, as the major goal of the study, which was measured by the return on assets (ROA), return on equity (ROE), earnings per share (EPS), and (EP), it showed the companies that achieved a level of profitability did reflect its performance through the ability of these companies to distribute profits, and increase its investment and growth.

\section{Recommendations}

The researcher arrived to the following recommendations, after reviewing the study results:

- The study recommended that investment companies and institutions in Jordan should support the real estate sector through increasing the investment in the sector; taking into consideration those levels of investment in this sector is much lower than investments in some foreign and Arabic countries by comparing the results of this study with numerous studies in several countries.

- The study recommended the need of governments to support this sector by giving investment facilities, and removing some of the imposed restrictions on this sector like reducing the imposed taxes on the profits of real estate companies in Jordan.

- On the academic and professional level, the study recommended that researchers and professionals need to conduct several studies and researches in the future to examine the companies in different sectors and identify the different capital structures patterns in it.

- The study recommended that researchers and professionals need to conduct further researches to examine the effect of capital structure on the profitability of unlisted real estate companies in the financial market, due to the fact that current study only dealt with the real estate companies listed in the stock market.

\section{References}

Abor J. (2007). "Debt policy and performance of SMEs: evidence from Ghanaian and South Africa firms". Journal of Risk Finance, Vol. 8, pp. 364-79.

Al-Karasneh, H \& Bataineh, A (2018) Does Corporate Governance Reduce Agency Costs in the Jordanian Industrial Companies? International Review of Management and Business Research, (7)2, 615-625.

Awunyo-Vitor, D., \& Badu, J. (2012). Capital structure and performance of listed banks in Ghana. Global Journal of Human-Social Science Research, 12(5).

Babalola (2012). The effects of optimal capital structure on firms' performances in Nigeria" Journal of Emerging Trends in Economics and Management Sciences (JETEMS), 3(2), 131-133.

Bataineh, A., \& Rababah, A. (2016). Comprehensive Income and Net Income, Which is more powerful in predicting Future Performance. International Journal of Academic Research in Accounting, Finance and Management Sciences, 6(2), pp 114-120.

Bennett, J. A., Sias, R. W., \& Starks, L. T. (2003). Greener pastures and the impact of dynamic institutional preferences. Review of Financial Studies, 16(4), 1203-1238.

Below, S. D., Stansell, S. R., \& Coffin, M. (2000). The determinants of REIT institutional ownership: tests of the CAPM. Journal of Real Estate Finance and Economics, 21(3), 263-278.

Boone, A. L., \& White, J. T. (2015). The effect of institutional ownership on firm transparency and information production. Journal of Financial Economics, 117, 508-533.

Buferna, F., Bangassa, K., \& Hodgkinson, L. (2005). Determinants of capital structure. Evidence from Libya. Research Paper Series, The University of Liverpool, 8.

Chan, S. H., Erickson, J., \& Wang, K. (2003). Real estate investment trusts: Structure, performance, and investment opportunities. USA: Oxford University Press.

Chen, C. R., Guo, W., \& Mande, V. (2003). Managerial ownership and firm valuation. Pacific-Basin Finance Journal, 11(3), 267-283. 
Chiang Y., Chang P. and Hui C. (2002). "Capital structure and profitability of the property and construction sectors in Hong Kong”, Journal of Property Investment and Finance, Vol. 20, pp. 434-53.

Cornett, M. M., Marcus, A. J., Saunders, A., \& Tehranian, H. (2007). The impact of institutional ownership on corporate operating performance. Journal of Banking and Finance, 31(6), 1771-1794.

Damodaran, (2001). "Corporate Finance." Theory and Practice (2nd edition). New York:Wiely

Del Guercio, D., \& Hawkins, J. (1999). The motivation and impact of pension fund activism. Journal of Financial Economics, 52(3), 293-340.

Desai, A. (2007). "Corporate Tax Avoidance and Firm Value.” Harvard University.

Downs, D. H. (1998). The value in targeting institutional investors: evidence from the five-or-fewer rule change. Real Estate Economics, 26(4), 613-616.

Elyasiani, E., \& Jia, J. (2010). Distribution of institutional ownership and corporate firm performance. Journal of Banking and Finance, 34, 606-620.

Ferreira, M., \& Matos, P. (2008). The colors of investors' money: The role of institutional investors around the world. Journal of Financial Economics, 88, 499-533.

Frankel, R., Kothari, S., \& Weber, J. (2006). Determinants of the informativeness of analyst research. Journal of Accounting and Economics, 41, 29-54.

Gillan, S. \& Starks, L. (2003). Corporate governance, corporate ownership, and the role of institutional investors: A global perspective. Journal of Applied Finance, 13, 4-22.

Ghosh, C., \& Sirmans, C. F. (2003). Board independence, ownership structure and performance: evidence from real estate investment trusts. Journal of Real Estate Finance and Economics, 26(2), 287-318.

Hazra, A., \& Gogtay, N. (2016). Biostatistics series module 6: correlation and linear regression. Indian journal of dermatology, 61(6), 593.

Heaton, J., 2002, Managerial Optimism and Corporate Finance, Financial Management 31(2), 33-45.

Ibrahim E. E. (2009), "The impact of capital-structure choice on firm performance: empirical evidence from Egypt". The Journal of Risk Finance, Vol. 10, pp. 477-487.

Kinsman, M., \& Newman, J. (1999, April). Debt level and corporate performance: an empirical analysis. In Proceedings of the 28th Annual Meeting of the Western Decision Sciences Institute (pp. 6-10).

Kyereboah-Coleman A. (2007). “The impact of capital structure on the performance of microfinance institutions".Journal of Risk Finance, Vol. 8, pp. 56-71

Majumdar S. and Chhibber P. (1999). "Capital structure and performance: evidence from a transition economy on an aspect of corporate governance". Public Choice, Vol. 98, pp. 287-305.

Milgrom, P., \& Roberts, J. (1992). Economics, organization, and management. Englewood Cliffs, NJ: Prentice-Hall.

Modigliani, Franco and Merton H. Miller. (1958). The Cost of Capital, Corporation Finance and the Theory of Investment. American Economic Review, 48:261-297.

Muritala, T. A. (2012). An empirical analysis of capital structure on firms' performance in Nigeria. International Journal of Advances in Management and Economics, 1(5) 116- 124.

O’Brien, P. C., \& Bhushan, R. (1990). Analyst following and institutional ownership. Journal of Accounting Research, $28,55-76$.

Pirzada, K., Mustapha, M. Z. B., \& Wickramasinghe, D. (2015). Firm Performance, Institutional Ownership and Capital Structure: A Case of Malaysia. Procedia-Social and Behavioral Sciences, 211, 170-176.

Rababah A, Bataineh A. (2016) Factors influencing balanced scorecard implementation. Research Journal of Finance and Accounting; 7(2): pp 204-212.

Shleifer, A., \& Vishny, R. W. (1986). Large shareholders and corporate control. Journal of Political Economy, 94, 461488.

Shleifer, A. \& Vishny, R. (1997). A Survey of corporate governance. Journal of Finance, 52 (2), 737- 783.

Sulaiman, M.A, (2001), "Leverage Determinants in the Absence of Corporate Tax System: The Case of Non-Financial Publicly Traded Corporations in Saudi Arabia" Managerial Finance 27, 261 - 275.

Uremadu, S. O., \& Efobi, U. R. (2012). The impact of capital structure and liquidity on corporate returns in Nigeria: Evidence from manufacturing firms. International journal of academic research in accounting, finance and management sciences, 2(3), 1-16.

Watson, D. and Head, A. (2007), "Corporate Finance Principles \& Practice*, 4th ed., Financial Times.

Zeitun R. and Tian G. (2007). "Capital structure and corporate performance: evidence from Jordan". Australasian Accounting Business and Finance Journal, Vol. 1, pp. 40- 53. 